\title{
O SABER E OS SABERES NA LEGISLAÇÃO SINODAL PORTUGUESA DA IDADE MÉDIA
}

\author{
Maria Alegria F. Marques* \\ alegriamarques@sapo.pt
}

\begin{abstract}
RESUMO: Ao longo da Idade Média e no cumprimento do seu múnus apostólico, os bispos portugueses foram reunindo o seu clero e, em conjunto, tentando traçar as linhas que lhes pareciam mais adequadas para a salvação do rebanho que lhes estava confiado. Na legislação produzida e que chegou até nós, pode aferir-se algo daquilo que os responsáveis do clero português entendiam como o saber necessário ao corpo clerical, bem como se pode olhar todo um conjunto de saberes que eram necessários ao desenrolar da vida religiosa e do clero no Portugal medievo. Bem assim, na interacção do clero com o povo cristão, ainda nos podemos cruzar com saberes vários, algumas vezes em práticas que conflituavam com a ideia de ortodoxia da hierarquia do clero medieval português.
\end{abstract}

PALAVRAS-CHAVE: Clero, Idade Média, saber e saberes.

\section{OS SÍNODOS MEDIEVAIS PORTUGUESES}

Desde cedo, foi prática, na Igreja cristã, a reunião dos bispos com o clero das suas dioceses ${ }^{1}$. Embora os autores se dividam relativamente à primeira reunião a que caberá o nome de sínodo (NAZ, 1965) ${ }^{2}$, pode dizer-se que eles estavam em vigor já no séc. IV, pois que o concílio de Niceia, reunido em 325, estipulou a necessidade, com tendência para obrigatoriedade, de o bispo reunir com o seu clero pelo menos duas vezes no ano, antes da Quaresma e no Outono (MARQUES, 2000, p. 419). Depois, os sínodos entraram na legislação e, nos tempos mais próximos àqueles em que nos iremos

\footnotetext{
* Doutora em História pela Universidade de Coimbra. Professora e pesquisadora da Faculdade de Letras da Universidade de Coimbra e do Centro de História da Sociedade e da Cultura.
} 
situar, era ponto assente que os bispos os deveriam reunir, anualmente; o Decreto de Graciano (D.18, c. 16), no séc. XII, recomendava a sua celebração anual (GAUDEMET, 1994, p. 384). Posteriormente, o IV Concílio de Latrão (c. 6) legislou no mesmo sentido da obrigatoriedade de tal reunião anual, determinando que ela seria a ocasião de publicação das normas estabelecidas nos concílios provinciais (ALBERIGO, 1994, pp. 506-509).

Os tempos que se seguiram, sobretudo o séc. XIII, com as lutas acesas entre Império e Papado, contribuíram, como se sabe, para um mal-estar e relaxamento das práticas da Igreja. De seguida, a crise a instalar-se na sociedade, o próprio clima de guerra que se agravou na Europa, com os intensos conflitos entre a França e a Inglaterra, tudo serviu de justificação para esse afrouxamento na vida da Igreja. Por tudo isto, no século XV, o concílio de Basileia (1433) legislou especificamente sobre a reunião (PAIVA, 2000, pp. 240-247; ALBERIGO, 1994, pp. 972-979), colocando a tónica na necessidade da sua reunião frequente, anual de tradição, que fixava depois da oitava da Páscoa, se outro costume não houvesse. Estatuiu a sua convocatória e presidência pelo prelado ou, em caso de impedimento, por um vigário; proibiu a presença de leigos na reunião; normalizou a abertura da reunião com um sermão pelo bispo e obrigou à leitura das constituições provinciais e sinodais em vigor e, na essência da reunião, mandou proceder à avaliação da vida e costumes do clero e dos fiéis, com vista à correcção dos erros e faltas detectadas.

Sendo certo que os bispos das arquidioceses podiam também reunir concílios, é importante esclarecer o que entender por sínodos. Serão muito próximos dos concílios, mas não são, juridicamente, a mesma coisa. Por exemplo, distinguem-se pela sua dimensão; enquanto o sínodo é uma reunião do clero de uma diocese, convocado pelo seu bispo, o concílio é uma assembleia de dignitários eclesiásticos, bispos e clérigos de outras dioceses, para questões pastorais, de doutrina, de fé.

De qualquer modo, são sempre reuniões do bispo com o seu clero, facto que levou a que, no início da história da Igreja se confundissem facilmente. Quanto à sua finalidade, uma vez que nos debruçaremos sobre sínodos portugueses, vejamos o que pensam deles alguns autores. Avelino de Jesus da Costa (1941) um dos autores a quem se deve a publicação do Synodicon português e, ele próprio, membro do cabido da Sé de Braga, entendeu que, através dessas reuniões, o bispo "procura adaptar a sua legislação às necessidade do tempos, para dar novo incremento à vida religiosa, renovar a disciplina eclesiástica, corrigir abusos e a novos males aplicar novos remédios" (p. 596- 
610); José Marques (1995), com a autoridade que o seu estatuto lhe confere, a de também membro do cabido da Sé de Braga, vê, nos sínodos, a oportunidade de o responsável diocesano "proceder à renovação espiritual da comunidade diocesana, mediante as mudanças de comportamento a introduzir, de acordo com a legislação aprovada", visando, dessa forma, "extirpar abusos graves, tanto na vida e actuação do clero, como no agir dos fiéis, que, aqui e além, parecia raiar a violação das normas da Fé e dos costumes" (p. 276).

Entre os autores leigos e mais recentes, Maria Alegria Marques (2003) já escreveu que as reuniões dos sínodos eram "momentos privilegiados de contacto entre o antístite e o seu clero, realizando-se um balanço da vida religiosa da diocese" (p. 33), enquanto José Pedro Paiva (2000), outro autor recente, considerou os sínodos como "assembleias que congregavam o clero de um arcebispado, ou bispado, convocadas pelo respectivo prelado, com o intuito de se avaliar o estado da vida religiosa, a situação clerical e de se proporem medidas de actuação nesses domínios” (p. 240). É patente a unanimidade na ideia de momento avaliador, de balanço do presente e de perspectiva sobre o futuro (AUBRUN, 1995, p. 19).

Já referimos que era direito e obrigação da autoridade episcopal, por si ou por seu representante autorizado, a convocatória e a presidência da assembleia sinodal. A ela deviam comparecer todos os convocados, clero catedralício, vigários, abades e priores, reitores e restante clerezia do bispado, sendo a sua presença obrigatória. Exceptuavam-se os clérigos doentes, de idade avançada ou que se encontrassem ausentes em viagem; em todo o caso, deviam justificar a sua falta e enviar um procurador, em sua substituição, sob pena de procedimento disciplinar do seu bispo ${ }^{3}$.

Por norma, um mês antes do sínodo, um edital circulava pelas freguesias e mosteiros a convocar os interessados ${ }^{4}$. Ao dia indicado, os clérigos convocados ou os seus representantes deveriam comparecer devidamente paramentados, os prelados com com as suas casulas albas e estolas, os abades de mosteiros beneditinos e os priores dos regrantes com as suas "mitras e bagos e (...) outros ornamentos necessarios pera se revestirem em pontifical", a demais clerezia com suas sobrepelizes "limpas e sãas" Não deveriam fazer-se acompanhar por cavaleiros, escudeiros, outras gentes armadas ou seculares, nem apresentar-se com sinais de ostentação e riqueza, que lhes eram vedados sempre, por natureza e condição ${ }^{6}$. Corriam o risco de lhes ser retirado o benefício correspondente à sua posição, em caso de falta, como dissemos. Os sínodos eram reuniões de curta duração, por norma menos de uma semana (MARQUES, 1995, p. 
$276)^{7}$, mas excessivamente ritualizadas, já que os participantes apresentavam-se em jejum, na abertura, com as vestes e insígnias próprias da celebração pontifical. Eram tratados os mais diversos assuntos, relacionados com o clero e os respectivos fiéis. Se a matéria eclesial era a predominante, também eram, ou podiam ser, discutidos assuntos de natureza económica e até política, sendo caso exemplar o sínodo do Porto, em 1344 (Synodicon, p. 347-348).

Não sabemos como decorriam as sessões; por certo, haveria opiniões diversas, mas talvez prevalecesse o ponto de vista do bispo, pois que, algumas vezes, se acha referência ao conselho e ao consentimento do cabido e sínodo. Apenas em dois casos se acha notícia de ter havido aprovação por unanimidade - nemine discrepante -, embora não se possa saber como ela se alcançou.

Dessas reuniões resultava um conjunto de normas, a aplicar ao clero e fiéis das respectivas dioceses, no sentido de uma busca de perfeição da vida das comunidades $^{8}$.

Em princípio, o seu alvo seria a vida espiritual; no entanto, e conhecida que é alguma indefinição ou indiferença dos poderes civis, régios ou senhoriais, por certas questões temporais, elas podem também conter normas de orientação da vida material das populações, tanto mais quanto lindassem com aspectos de natureza espiritual. Tais normas constituem o que, hoje, conhecemos como constituições sinodais. Tanto reforçam, adaptam ou complementam legislação anterior, como apresentam inovação considerando matérias até então fora de reflexão ${ }^{9}$. De qualquer forma, como resultado que eram de reuniões presididas pelos bispos, também não é de esquecer que elas podem representar muito mais as preocupações e o pensamento dos bispos e do clero do seu círculo que, propriamente, do conjunto, heterogéneo, daquele que participou nas reuniões. Por outro lado, na avaliação que tais normas permitem fazer acerca da vida das comunidades, é imperioso ter presentes as palavras de José Marques (1995), quando afirma:

A sistemática utilização das constituições sinodais como fontes históricas tem de ser feita com critério, para evitar generalizações falaciosas. Na verdade, trata-se predominantemente de normas jurídicas de direito diocesano ou particular e morais que, embora elaboradas a partir do conhecimento de alguns casos em concreto, têm uma função preventiva, mesmo quando a sua renovação se tornou necessária (p. 277). 
Pelo exposto e atendendo à vetustez da maioria das dioceses portuguesas, seria expectável que possuíssemos um elevado número de constituições sinodais em Portugal, inclusivamente para os tempos medievais. Mas isso não é verdade. Bem pelo contrário; são relativamente poucas as notícias de sínodos e muito poucas as constituições que conhecemos, como poderemos concluir dos Quadros seguintes, começando por um quadro-síntese, de leitura rápida e conclusões abreviadas:

$$
\text { I - Quadro-resumo }{ }^{10}
$$

Sínodos medievais portugueses (1191-1500)

\begin{tabular}{|l|l|l|l|l|l|l|l|l|l|l|l|}
\hline \multirow{2}{*}{ N. $^{\circ}$} & Braga & Coimbra & Évora & Guarda & Lamego & Lisboa & Porto & V. Minho & Viseu & Total & $\%$ \\
\cline { 2 - 12 } & 29 & 3 & 8 & 1 & 2 & 14 & 11 & 4 & 2 & 74 & $\mathbf{1 0 0}$ \\
\hline Notícia & 17 & 1 & 2 & 0 & 1 & 7 & 7 & 0 & 2 & 37 & $\mathbf{5 0 , 0}$ \\
\hline Texto & 12 & 2 & 6 & 1 & 1 & 7 & 4 & 4 & 0 & 37 & $\mathbf{5 0 , 0}$ \\
\hline S. XII & 0 & 0 & 0 & 0 & 0 & 1 & 0 & 0 & 0 & 1 & $\mathbf{1 , 4}$ \\
\hline S. XIII & 5 & 1 & 1 & 0 & 1 & 6 & 2 & 0 & 1 & 17 & $\mathbf{2 3 , 0}$ \\
\hline S. XIV & 16 & 2 & 4 & 0 & 1 & 4 & 5 & 0 & 0 & 32 & $\mathbf{4 3 , 2}$ \\
\hline S. XV & 7 & 0 & 3 & 1 & 0 & 3 & 4 & 4 & 1 & 23 & $\mathbf{3 1 , 0}$ \\
\hline S. XVI & 1 & 0 & 0 & 0 & 0 & 0 & 0 & 0 & 0 & 1 & $\mathbf{1 , 4}$ \\
\hline
\end{tabular}

Como se pode concluir, foi o séc. XIV o que mais assistiu a reuniões deste tipo (32), ou o que mais provas nos legou, delas. Por ordem decrescente, seguem-se os séculos XV, XIII, XII e XVI, como fica expresso. E, no séc. XIV, a sua segunda metade proporcionou 19 dessas 32 reuniões, o que parece indicar que, à medida que o século avançava $^{11}$, mais o clero português, particularmente o da arquidiocese de Braga (com 10 reuniões nesse período ${ }^{12}$, num total de 16 , em todo o século) sentia necessidade de reunir e discutir os problemas que o afligiam e perturbavam a sociedade portuguesa. Ao contrário do que seria de esperar, o séc. XV não logrou aguentar esse ritmo - ou não deixou vestígios ou notícias - de reunião das assembleias sinodais (PAIVA, 2000, p. 240-247; SOARES,1997, p.119-138).

Procedendo ao seu desdobramento, poderemos apreciar as reuniões sinodais por dioceses, datas, bispos e número de constituições conhecidas (Quadro II). 


\section{Quadro II}

Sínodos medievais portugueses (1191-1500)

\section{II-1. Arquidiocese de Braga}

\begin{tabular}{|c|c|c|}
\hline Data & Arcebispo & Legislação \\
\hline 1214 & D. Estêvão Soares da Silva & \\
\hline 1281 & D. Frei Telo & 49 constituições \\
\hline $1285 ?$ & D. Frei Telo & 7 \\
\hline $1286 ?$ & D. Frei Telo & 3 \\
\hline 1296 & D. Martinho Pires de Oliveira & 1 \\
\hline 1301 & D. Martinho Pires de Oliveira & 13 \\
\hline 1326 & D. Gonçalo Pereira & 9 \\
\hline 1329 & D. Gonçalo Pereira & \\
\hline 1330 & D. Gonçalo Pereira & \\
\hline 1333 & D. Gonçalo Pereira & 15 (em português) \\
\hline 1342 & D. Gonçalo Pereira & \\
\hline 1364 & D. João de Cardaillac & \\
\hline 1366 & D. João de Cardaillac & \\
\hline 1374 & D. Lourenço Vicente & 2 \\
\hline 1379 & D. Lourenço Vicente & \\
\hline 1383 & D. Lourenço Vicente & \\
\hline 1387 & D. Lourenço Vicente & \\
\hline 1391 & D. Lourenço Vicente & \\
\hline 1392 & D. Lourenço Vicente & \\
\hline 1394 & D. Lourenço Vicente & \\
\hline 1398 & D. Martinho Afonso Pires da Charneca & \\
\hline 1402 & D. Martinho Afonso Pires da Charneca & 2 \\
\hline $1424 / 1425$ & D. Fernando da Guerra & \\
\hline 1430 & D. Fernando da Guerra & 1 \\
\hline 1435 & D. Fernando da Guerra & 7 \\
\hline 1439 & D. Fernando da Guerra & \\
\hline 1477 & D. Luís Pires & 63 \\
\hline 1488 & D. Jorge da Costa & \\
\hline 1505 & D. Diogo de Sousa & 58 \\
\hline
\end{tabular}

\section{II-2. Diocese de Coimbra}

\begin{tabular}{|l|l|l|}
\hline \multicolumn{1}{|c|}{ Data } & \multicolumn{1}{|c|}{ Bispo } & \multicolumn{1}{c|}{ Legislação } \\
\hline $1247-1267$ & D. Egas Fafes & 2 \\
\hline 1307 & D. Estêvão Anes Brochado & 5 \\
\hline Finais séc. XIV & $?$ & 7 \\
\hline
\end{tabular}


II-3. Diocese de Évora

\begin{tabular}{|l|l|l|}
\hline \multicolumn{1}{|c|}{ Data } & \multicolumn{1}{c|}{ Bispo Legislação } \\
\hline $1267-1283$ & D. Durando Pais & \\
\hline 1344 & D. Martinho Afonso & 8 \\
\hline $1352-1355$ & D. João Afonso & \\
\hline 1372 & D. Martinho III & 1 \\
\hline 1378 & D. Martinho III & 1 \\
\hline $1420-1423$ & D. Pedro de Noronha & 1 \\
\hline 1466 & D. Luís Pires & $1(39)$ \\
\hline 1467 & D. Luís Pires & 1 \\
\hline
\end{tabular}

II-4. Diocese da Guarda

\begin{tabular}{|c|l|l|}
\hline \multicolumn{1}{|c|}{ Data } & \multicolumn{1}{|c|}{ Bispo } & \multicolumn{1}{c|}{ Legislação } \\
\hline 1500 & D. Pedro Vaz Gavião & 94 \\
\hline
\end{tabular}

\section{II-5. Diocese de Lamego}

\begin{tabular}{|l|l|l|}
\hline \multicolumn{1}{|c|}{ Data } & \multicolumn{1}{|c|}{ Bispo } & \multicolumn{1}{c|}{ Legislação } \\
\hline 1252 & D. Egas Pais & 3 \\
\hline 1368 & D. Lourenço & \\
\hline
\end{tabular}

II-6. Diocese de Lisboa

\begin{tabular}{|l|l|l|}
\hline \multicolumn{1}{|c|}{ Data } & \multicolumn{1}{c|}{ Bispo } & \multicolumn{1}{c|}{ Legislação } \\
\hline 1191 & D. Soeiro Anes & \\
\hline $1210-1232$ & D. Soeiro Viegas & 33 \\
\hline 1240 c. & D. João I ou D. Aires Vasques & 12 \\
\hline 1248 & D. Aires Vasques & 3 \\
\hline 1264 & D. Mateus & 2 \\
\hline 1268 & D. Mateus & 3 \\
\hline 1271 & D. Mateus & 30 \\
\hline 1307 & D. João Martins de Soalhães & \\
\hline 1315 & D. Frei Estêvão & \\
\hline 1324 & D. Gonçalo Pereira & 33 \\
\hline $1393-1402$ & D. João Anes & \\
\hline 1403 & D. João Esteves de Azambuja & \\
\hline 1462 & D. Afonso Nogueira & D. Jorge da Costa \\
\hline $1484 ?$ &
\end{tabular}

Hist. R., Goiânia, v.18, n. 1, p. 91-120, jan. / jun. 2013 
II-7. Diocese do Porto

\begin{tabular}{|l|l|l|}
\hline \multicolumn{1}{|c|}{ Data } & \multicolumn{1}{|c|}{ Bispo } & \multicolumn{1}{c|}{ Legislação } \\
\hline $1247-1260$ & D. Julião Fernandes & 1 \\
\hline $1261-1265$ & D. Vicente Mendes & \\
\hline 1326 & D. João Gomes & \\
\hline 1344 & D. Pedro Afonso & 3 \\
\hline 1360 & D. Afonso Pires & 3 \\
\hline 1371 & D. Afonso Pires & \\
\hline $1391-1399$ & D. João Esteves de Azambuja & \\
\hline 1430 & D. Antão Martins de Chaves & \\
\hline $1447-1453$ & D. Gonçalo Anes & $60+1$ \\
\hline $1465-1495$ & D. João de Azevedo & \\
\hline 1496 & D. Diogo de Sousa & \\
\hline
\end{tabular}

II-8. Diocese de Viseu

\begin{tabular}{|l|l|l|}
\hline \multicolumn{1}{|c|}{ Data } & \multicolumn{1}{|c|}{ Bispo } & Legislação \\
\hline 1251 & D. Pedro Gonçalves & \\
\hline Finais séc. XV & D. Fernando G. Miranda & \\
\hline
\end{tabular}

\section{II-9. Administração Eclesiástica de Valença do Minho}

\begin{tabular}{|l|l|l|}
\hline \multicolumn{1}{|c|}{ Data } & \multicolumn{1}{|c|}{ Responsável } & \multicolumn{1}{c|}{ Legislação } \\
\hline 1444 & D. João Afonso Ferraz & 30 \\
\hline 1472 & D. João Afonso Ferraz II & 5 \\
\hline 1482 & D. Frei Justo Baldino & 9 \\
\hline 1486 & D. Frei Justo Baldino & 9 \\
\hline
\end{tabular}

Da leitura destes nove sub-quadros, ressalta, em primeiro lugar, a predominância absoluta da arquidiocese de Braga, com o maior número de reuniões sinodais, 29 , no total de 74, bem como se assinala um extraordinário empenho, neste campo, dos arcebispos D. Gonçalo Pereira e D. Lourenço Vicente, ainda que deste não se conheça qualquer constituição sinodal. Sobressai ainda uma outra diocese, a Guarda, no pólo oposto, com testemunho de uma única reunião, no séc. $\mathrm{XV}$, e duas dioceses, Viseu e Lamego, que nos deixaram prova de apenas duas reuniões, em cada uma, durante os quatro séculos considerados. Por ausência absoluta, impõe-se a diocese de Silves. 
Das restantes dioceses, afinal aquelas que se apresentam com números médios, Lisboa, Porto e Évora são as que mais se distinguem, (14, 11 e 8, respectivamente), deixando Coimbra num lugar muito abaixo da média de reuniões, pois que apresenta apenas registo de três reuniões dos séculos XIII e XIV. São, pois, números merecedores de reflexão, tendo em vista as disposições conciliares relativamente à periodicidade das reuniões sinodais: ou elas eram letra morta ou perdeuse muita documentação. Todavia, a inclinação pende para a primeira hipótese, uma vez que se não há documentação, também não há notícias, nem esparsas, de realização de sínodos, o que se revela muito estranho, no caso de se terem efectuado.

Se bem que prevenida acerca dos problemas que envolvem este tipo de documentação, mormente no que diz respeito ao seu percurso secular, a análise da cronologia das reuniões sinodais deixa perceber uma enorme oscilação na sua realização. Mesmo nas séries longas, como nos casos das dioceses de Braga, Lisboa, Porto e Évora, percebe-se que há alguma, por vezes notória, variação na periodicidade das reuniões. Essa oscilação pode ser devida a vários factores, nomeadamente alguma inquietação que a sucessão e nomeação dos bispos acarretavam, a que podia ainda juntar-se o facto de alguns serem estrangeiros, logo absentistas, senão sempre, pelo menos durante algum tempo ${ }^{13}$. Por outro lado, talvez se possa equacionar também a real necessidade de reuniões anuais, sobre as mesmas matérias, em tempos de comunicações difíceis e de dificuldades notórias entre o clero, sobretudo à medida que se afastasse da cidade e entrasse no mundo rural.

Porém, vistas de outra óptica, a do clero dirigente, as reuniões sinodais eram oportunidade para a recepção de mais uma contribuição do seu clero, o sinodático, a que, por vezes, acrescia a cera.

\section{A MATÉRIA SINODAL. AS CONSTITUIÇÕES}

Bem diferente das reuniões sinodais e das suas notícias chegadas até nós podem ser as constituições sinodais. Na verdade, nem conhecemos matéria de todas as reuniões de que há notícia, nem todas as reuniões produziram legislação na mesma quantidade e qualidade. Por isso, torna-se também interessante analisar os sínodos sob este ponto de vista ${ }^{14}$.

Dos sub-quadros apresentados ressalta quer um número muito razoável de sínodos cuja existência apenas se conhece por uma qualquer notícia, pois que, deles, mais não ficou, quer uma diversidade muito grande do número de constituições que, 
hoje, deles conhecemos ${ }^{15}$. Donde ter que ser forçosamente diverso o conhecimento transmitido por elas acerca das respectivas dioceses, havendo mesmo uma diocese, a de Viseu, sobre a qual, existindo notícias de realização de sínodos, nada se pode saber, em concreto, pois não há matéria sinodal. No outro extremo, veja-se a pobreza e a riqueza da diocese da Guarda: de um único sínodo chegaram-nos 94 constituições, o que nos revela um extraordinário painel da vida religiosa e do quotidiano de múltiplas práticas nessa enorme diocese. Igualmente se conclui que, tendo diminuído o número de reuniões no séc. $\mathrm{XV}$, aumentou o número de constituições produzidas, o que significa que o clero português não deixou de estar atento às realidades que o rodeavam, ou até, mesmo, lhes dedicou mais atenção.

Aprovadas as constituições, ficava o clero diocesano obrigado a fazer escrevê-las em livro próprio e, assim ordenadas, eram apresentadas ao bispo diocesano para as assinar e mandar selar, dentro de um prazo certo outorgado pelo bispo. A leitura das várias constituições permite concluir que este prazo foi evoluindo, desde o ano até alguns poucos meses. Assim, em 1281, D. Frei Telo, arcebispo de Braga, determinava que os responsáveis eclesiásticos da sua diocese procurassem mandá-las escrever "nos seus livros" "dentro de um ano"; por sua vez, D. Luís Pires, seu sucessor na segunda metade do séc. XV, já fazia encurtar significativamente esse prazo, para cerca de três meses ${ }^{1}$. Para facilitar e incentivar a prática, o processo era isento de pagamento do selo.

Uma vez aprovadas, as constituições sinodais entravam imediatamente em vigor. Como se destinavam ao clero e ao povo, os responsáveis deveriam dar-lhes dois encaminhamentos, um destinado ao clero, outro, ao povo que os clérigos tinham a seu cargo. Num exercício de auto-formação, os clérigos deveriam reunir-se, amiúde, nas igrejas "e antre sy", lerem "as dictas constituiçõoes pera as saberem melhor e poderem aproveitar a sy mesmos e a seus parochianos”. Já para a sua transmissão ao povo, o clero diocesano em cada domingo, na missa maior, deveria publicá-las ${ }^{16}$, lê-las e notificar "ao poboo declaradamente em alta voz aquellas constituiçõoes que tocam aos leiguos" $" 17$. E a importância era tal que estas últimas determinações eram acompanhadas de uma sanção pecuniária. Já o sínodo de Braga, de 1505, foi mais explícito quanto à obrigação: os clérigos deveriam lê-las, ao povo, aos domingos e dias de festa, isto é, "cada domingo e cada festa duas ou tres, em tal modo que cada huum anno lhes sejam leudas todas tres vezes" $" 18$. 
Se estas são determinações claramente expressas em assembleias sinodais realizadas no último quartel do séc. XV ou início do XVI, elas não constituíam inovação, antes eram sinal de continuidade de práticas. Contudo e também segundo estas mesmas constituições, ainda deixando perceber que não se estava perante qualquer novidade, as determinações sinodais não passavam, muitas vezes, de letra morta. Tanto assim que passados três anos de as ter promulgado, ainda o acima citado arcebispo D. Luís Pires se indignava de haver clérigos que "nunca dello [cópia das constituições] curarom nem oje curam", em atitude que o pastor entendia como de "maldade, despreço, desobediencia, negligencia e contumacia"2. E era ele ainda que, atendendo a "que tanto bem e serviço de Deus nom se perca e tantas booas e sanctas cousas nom sejam dadas em esqueecimento, mas que al de menos em alguum lugar jaçam vivas e nom mouram de todo" mandava fazer um exemplar que assinou, fez selar, juntar encadernar e, assim organizadas mandou "com pregos de ferro e com cadeea de ferro prender aquy nesta nossa cadeira archiepiscopal desta nossa see, e onde nossos predecessores acustumarom e nos custumanos nos assentar, pera os que quiserem veer e ler per ellas ou aver copia dellas" ${ }^{3}$.

E, como indicámos em lugar próprio, as constituições versam matéria muito distinta, desde a formação - intelectual e moral - do clero, liturgia, vida religiosa do povo, à defesa dos bens da Igreja e do estatuto do clero.

\section{O SABER E OS SABERES NAS CONSTITUIÇÕES SINODAIS PORTUGUESAS MEDIEVAIS}

A legislação sinodal portuguesa medieval não tem suscitado muita atenção por parte dos estudiosos. E quando acontece, tem-no sido muito sob a óptica da formação e da vida e costumes do clero. Nós mesma já a estudámos em perspectivas bem diversas, quer na óptica da sociedade e do entendimento que os responsáveis da igreja portuguesa tinham das relações dos cristãos com as minorias religiosas do reino, em tempos medievais, quer quanto ao entendimento que faziam da casa de Deus e do seu uso.

Hoje, porém, é bem diverso o olhar que pretendemos lançar sobre esses registos que o clero nos deixou, de si mesmo. É nosso desiderato tentar perceber que 
saber e que saberes convocava a condição clerical, bem como a sociedade com que interagia, de mais perto e que, por isso, ficaram referenciados nas constituições sinodais.

Ao colocarmo-nos nesta perspectiva, teremos que, em primeiro lugar, definir quer o saber, enquanto conceito, quer o saber tendo em conta o grupo social específico que nos ocupará.

Assim, entendemos por saber o conjunto de conhecimentos adquiridos sobre determinada matéria, que permitia habilitações próprias, mas sobretudo, competências específicas a um certo grupo social, no caso, o clero, que é, por coincidência, também o produtor da documentação que analisamos. Seria esse saber e essas competências de carácter $\operatorname{cognitivo}^{4}$ que o tornariam capaz de desempenhar a sua função social com eficácia.

\subsection{O(s) saber(es) do clero}

A leitura das constituições sinodais dão-nos indicações acerca dessas competências, tanto quando criticam a ignorância do clero, como quando indicam os conhecimentos de que os seus membros se deveriam munir.

Segundo elas, a começar pelas mais antigas que se conhecem da arquidiocese de Braga, relativas ao sínodo de 1281, todo o clérigo deveria saber falar latim e conhecer os estudos de gramática. Nenhum indivíduo poderia ser promovido a ordens sacras, ditas maiores, que começavam pelo sub-diaconado ${ }^{5}$, se não soubesse falar latim, bem como se fosse ignorante ou incompetente no canto e na leitura (MARQUES, 1990, p. 228, nota 360) ${ }^{6}$. Estas determinações vão repetir-se ao longo dos séculos, um pouco por todas as dioceses, em sinal evidente de que provinham de um diagnóstico de carácter geral e de que as soluções que se lhe iam apontando não eram acatadas ${ }^{7}$. Justificava-se a exigência: dever-se-ia acautelar que os clérigos "nam digam vicio no que leerem", "saibam reger o breviairo" e dizer a missa "manso e apontadamente, especialmente as pallavras da sacra", além de que deviam administrar bem os sacramentos, sem errarem as fórmulas litúrgicas "nas palavras nem nas sillabas que ham de dizer, ca muitas vezes por nom saberem leer e ministrar os dictos sacramentos e o que leem nom hir bem liido e decrarado, alguuns nom receberam sacramentos que 
cuidam teer recebidos" ${ }^{\prime 8}$. Em todo o lado, a leitura exigia aprendizagem e treino, para que os sacerdotes "leam desenbargadamente e perfectamente celebrem os officios divinos e saibam dar os sacramentos e espiciallmente que bem e verdadeiramente leeam a sacra e apontem e hordepnem, nom correndo nem sincopando nem fazendo antrevallo nem leixando allgûa cousa do que deve de dyzer em ella ou emadendo algûa pallavra mais que aquello que se deve de dizer segundo a hordepnaçom della e pello livro"9.

Já quanto ao canto, no caso dos salmos (e, por certo, nos demais casos) deveriam ser recitados com clareza e com respeito pela pontuação ${ }^{10}$. Deveriam ser cantados "pellas bocas dos homens e nom per outros stromentos" o Gloria in excelsis Deo "que hé cantar angélico" e o Credo in unum Deum "que hé conffissom da sancta fé católica"11. As horas canónicas deveriam ser cantadas "em voz emssoada", com "pausas e divisõoes nos versos, nom estirando a voz em fim do versso, mas fazendo o fim curto. E o pronunciar da letra longa em tal guisa que nom sincopando nem enburilhando digam e declarem toda a letra" ${ }^{\prime 2}$.

Esta preparação intelectual era porta de acesso a outros estudos ou de entrada noutros saberes. Assim a liturgia, a catequética e a prédica. Quanto à primeira, a necessidade do seu conhecimento está claramente expressa no sínodo de Braga reunido pelo arcebispo D. Frei Telo, em $1285^{13}$. Aí se acha clara e pormenorizadamente estabelecida a liturgia do baptismo e da consagração, pelo menos no que dizia respeito ao seu formulário ${ }^{14}$. Embora o venhamos a encontrar em mais algumas constituições sinodais da Igreja portuguesa medieval ${ }^{15}$, é nas determinações deste segundo sínodo do arcebispo D. Frei Telo que elas encontram uma formulação mais precisa e mais completa.

$\mathrm{Na}$ verdade, a preocupação com os sacramentos e a sua administração era um cuidado recorrente entre os bispos portugueses, na Idade Média. Baptismo, penitência, eucaristia, matrimónio e extrema-unção estão frequentemente presentes nas constituições, sinal de que havia necessidade de transmitir ao clero diocesano as linhas fundamentais da sua administração. Frequentemente, e em relação ao matrimónio, tais considerações eram também uma forma de fazer passar as determinações do direito 
canónico que lhe diziam respeito, sobretudo se tivermos em vista o problema do parentesco e outros impedimentos à obtenção de tal sacramento ${ }^{16}$.

Mas não era apenas o cuidado com a liturgia sacramental que preocupava os responsáveis diocesanos. Da leitura das constituições sinodais são de salientar a atenção a ter com os livros litúrgicos a seguir ${ }^{17}$, a preocupação com o conhecimento e o cumprimento do calendário litúrgico e as festas da Igreja ${ }^{18}$, os dias de jejum ${ }^{19}$, o lugar central da Igreja na vida dos fiéis de Cristo ${ }^{20}$.

Da leitura das constituições sinodais ressalta que o latim era a língua da liturgia. A celebração da missa era feita em latim, numa prática que ainda chegou até nós, mas cuja lembrança se vai esvaindo, e os fiéis apenas lhe assistiam. Leiam-se as determinações sobre a liturgia baptismal e eucarística do sínodo de Braga de 1285 e aí se acharão os respectivos formulários na língua de Cícero. No entanto, havia abertura mental suficiente para o emprego da língua vulgar, bem como o caminho seria já para a rotina do seu uso ${ }^{21}$.

Num conceito muito alargado de liturgia e tendo presente o sacerdote como o seu ministro, vemos os sínodos a responsabilizá-los por um conjunto de tarefas que iam da lavagem de alfaias (corporais e palas) e pias de baptismo à dos recipientes que contivessem as cinzas da queima de paramentos e objectos litúrgicos danificados, sem possibilidade de mais uso ${ }^{22}$.

Pode dizer-se que estas últimas tarefas não necessitavam de preparação de maior, que a sua prática era intuitiva. Concedemos que assim fosse; porém, na sua base, não deixa de fazer apelo a algum saber ou, pelo menos, saber fazer, se atendermos à sua justificação $^{23}$ e às técnicas de lavagem da época, sem as comodidades a que hoje recorremos.

No seu múnus de pastores de homens, aos clérigos era ainda incumbida a prédica. Desde cedo que esta obrigação se encontra registada (Braga: 1326, c. 5 (Synodicon, p. 41-42). Embora pouco se conheça acerca dela, cremos que teremos de considerar a arte da palavra que fazia chegar a mensagem ao público, quer o problema das temáticas a abordar. Longe de estereótipos mais ou menos recentes de meio século, 
parece-nos, contudo, que deve aceitar-se alguma preocupação com essa arte da palavra, isto é, a retórica, e ainda o interesse acerca de temas hagiográficos e teológicos. Os primeiros ligar-se-iam à vida dos santos protectores das comunidades e os segundos à catequética, mormente na insistência da prática das virtudes. O seu veículo seria a linguagem vulgar, afinal a expressão do quotidiano, aquela que os homens comuns entendiam.

Por fim, consideremos a catequética, tarefa imprescindível à difusão da doutrina e ao cuidado com o rebanho que cada beneficiado tinha a seu cargo. Era um meio privilegiado para cativar os homens para a mensagem do Salvador. É, por isso, uma matéria bastante focada nos diversos sínodos.

Seriam estas as principais tarefas de um pároco, pelo que eram elas também que mais cuidados recebiam dos dirigentes diocesanos, na responsabilidade que entendiam relativamente ao seu clero e aos seus fiéis. Representavam também as diversas vias de interacção do clero com os fiéis da Igreja de Cristo.

Ao propósito delas, convirá reflectir sobre a transmissão da mensagem aos fiéis, o que nos coloca ainda na catequética. No reino da oralidade, como o foi a Idade Média, ela seria também ministrada em latim, no que diz respeito aos formulários das orações, que eram as principais da doutrina da Igreja: Pater noster, Ave Maria, Credo, para logo se desdobrarem "per lingoajem", de forma a serem compreendidas por $\operatorname{todos}^{24}$.

Além destas orações, exigia-se também que os clérigos transmitissem os preceitos da lei - os mandamentos da lei de Deus -, as obras de misericórdia, os sete pecados mortais, as virtudes teologais e cardinais. E tudo isto se faria "per lingoagem", existindo um tempo próprio consignado à catequese de cada um daqueles conteúdos ${ }^{25}$, oportunidade para os homens aprenderem a rezar, conhecerem para crer, aprenderem para cumprir e saberem para se guardarem ${ }^{26}$. O tempo havia de trazer a codificação de todos os ensinamentos tidos por necessários à formação cristã dos portugueses da Idade Média. E é num dos sínodos que estamos a analisar, o do Porto: 1496, que se encontra "o que poderíamos chamar o primeiro catecismo português", nas palavras dos editores do Synodicon (p. 405-414). Em concomitância, surgia a obrigatoriedade de existência de livros ou cadernos ou simples registos, nas igrejas, onde tudo isso deveria ser escrito, de 
modo aos sacerdotes poderem "estudar e saber", "com muita diligencia e perseverancia" 27 , a fim de poderem cuidar das consciências, dos outros e suas, com mais saber.

Porém, ao clero e na prática das suas funções era exigido o domínio de outras práticas, logo, de outras competências. Aos clérigos, era também exigido que conhecessem, no mínimo, rudimentos de música. O domínio do órgão era o mais aconselhado ao seu estado e as suas capacidades na matéria deveriam ser colocadas apenas ao serviço de Deus, tangendo, eles, "cousa espiritual que geere devaçom nos coraçõoes dos ouvintes e nom garredice" (Synodicon, p. 87).

Ao contrário do que muitas vezes se pensa, um clérigo não era apenas um homem dedicado às coisas divinas. $\mathrm{O}$ múnus clerical implicava que os seus protagonistas tivessem também que atender a coisas do mundo, algumas delas imprescindíveis até ao serviço de Deus. Eles deveriam cuidar da igreja, dos objectos e alfaias litúrgicas, dos paramentos, e, em última instância, dos bens das igrejas, afinal uma parte muito considerável da base material da sustentação delas e dos clérigos que as serviam.

Além de que, num sentido muito imediato, muito humano, teremos que ver sempre um homem na figura de um sacerdote. Sendo certo que ele está revestido de funções muito próprias, que fazem dele um intermediário entre a humanidade e Deus, ele é, em primeiro lugar um homem, revestido da sua mais profunda natureza, sujeito às necessidades de qualquer outro, no que tocava à subsistência. Contudo, deixamos de lado este campo, do comer e do vestir, tão da vida comum eles eram. O mesmo não poderemos fazer em relação ao barbeiro, cujos serviços os responsáveis diocesanos desejavam que o clero requeresse amiudadamente, pois lhe impunha quer o corte dos cabelos, quer o cuidado da coroa.

Nessa humanidade que conformava os clérigos, na sua essência, teremos também que entender que eram seres propícios à solicitação para outras tarefas e à sedução de faltas e vícios que, podendo ser de todos, eram menos tolerados a um sacerdote. Através das constituições sinodais, percebe-se que assim era também na Idade Média e que os responsáveis eclesiásticos diocesanos tinham bem essa consciência (PEREIRA, 1978). Isso mesmo se nos afigura quando proíbem, aos clérigos, certas actividades que exigiam certos saberes ou o uso de bens que, sendo 
necessários, podiam apresentar excepção e saber muito especial. Neste último caso contavam-se os artigos de luxo que, por vezes, alguns ostentavam, e que eram fruto do labor de mestres especializados, alfaiates ${ }^{28}$, ourives ${ }^{29}$, ferreiros e alfagemes ${ }^{30}$.

No caso de actividades interditas ou, no mínimo, censuradas, aos clérigos algumas provinham do seu saber, da sua preparação intelectual, como era o caso da capacidade de advogarem ${ }^{31}$ ou de exercerem o ofício de tabelião ${ }^{32}$, eventualmente serem mordomos de fidalgos e poderosos ${ }^{33}$. Outras, porém, eram tão só práticas do quotidiano que, exigindo saber, capacidade específica, lhes eram proibidas pelas leis próprias do clero, como os negócios e mercancias ${ }^{34}$; outras, ainda, poderiam revestir-se de carácter impuro, quando não ilegal, proibido pelas leis da Igreja e, por vezes, até dos homens. Estão, neste caso, a frequência de gentes ligadas a artes divinatórias ${ }^{35}$, a prática do toureio, a luta, o bailar, os jogos de azar, $\operatorname{cartas} \operatorname{dados}^{36} \mathrm{e}$, mesmo, a ilicitude de falsear a moeda ${ }^{37}$.

Bons conhecedores da natureza humana, os responsáveis diocesanos sabiam que, por vezes, havia necessidade de alguma transigência, pois que se evitariam males maiores. Era o caso da possibilidade de os clérigos poderem, ou não, praticar a arte da caça. Por princípio, não o deveriam fazer, pois que não só os aproximava, perigosamente, dos seculares, como podia conflituar com as suas obrigações do mundo eclesial. Porém, bem sabiam que, no caso de "evidente necessidade de aliviamento de infirmidade ou tristeza" a caça poderia ajudar o homem que se escondia sob a condição de um clérigo (Braga: 1477, c. 39; Synodicon, p. 111-112).

Se, até ao momento, temos procurado emoldurar os saberes do clero, enquanto agente social na Idade Média, há que ter presente que, ainda no seu múnus, o clero se cruzava com um conjunto de práticas e exigências que exigiam saberes, competências próprias, as quais, não sendo exercidas directamente pelos clérigos, reclamavam que eles por elas se responsabilizassem. Se é certo que algumas lhe eram mais ou menos necessárias, pois que de recurso ocasional, outras estavam sob o seu 
alcance enquanto agentes da Igreja como instituição, e outras, ainda, deveriam ser alvo da sua atenção e correcção enquanto condutores de homens.

No primeiro caso, tratava-se de artes que ajudavam à manutenção das condições materiais do culto divino. Atendo-nos às constituições sinodais, vemos que os clérigos eram responsáveis pela guarda e recato dos santos óleos, livros, paramentos, alfaias litúrgicas, embelezamento dos templos. Não raramente, era-lhes indicado que mandassem fazer caixas e arcas para a sua guarda ${ }^{38}$. Ou que cuidassem das alfaias do culto, cálices, cruzes, turíbulos, custódias e outras mais, desde logo procedendo ao seu inventário, com a respectiva descrição. Ou, ainda, que cuidassem das imagens dos santos, nas sua pintura, nos seus retábulos e nas suas esculturas em pedra e madeira ${ }^{39}$. Ora, para tudo isto, os clérigos tinham que conhecer, para poderem recorrer a quem sabia, a mestres de ofícios que lhes pudessem fornecer os serviços em causa. E, como gestores, embora sem o saberem ou sem o quererem, deveriam escolher os melhores na arte, o que implicava saber. Contudo, nesses cuidados, os clérigos poderiam, por vezes, ver a sua possibilidade de escolha reduzida ou cerceada. Por exemplo, as alfaias litúrgicas da eucaristia em caso algum (pesagem ou conserto) deveriam ser entregues a mãos impuras, de judeus, mouros e infiéis ${ }^{40}$, bem como não poderiam recorrer aos seus serviços e de mulheres das suas religiões para a confecção e reparo de vestes sagradas ${ }^{41}$.

Vista, cada igreja, como uma instituição em si mesma, de âmbito mais ou menos reduzido ou alargado, conforme a comunidade humana de que era cabeça, o clérigo seu responsável tinha a seu cargo a administração dos respectivos bens. Não lhe exigindo um saber específico, ainda assim, requeria-lhe o conhecimento de alguns pressupostos. Assim, deveria conhecer alguns princípios acerca da gestão dos bens temporais, móveis e imóveis, desde logo, na sua identificação e conhecimento, através de realização de tombos e inventários, mas também no que poderiam penhorar ou alienar e em que condições ${ }^{42}$, a que se juntava a matéria de aforamento ou arrendamento dos bens fundiários ${ }^{43}$. Deveria ainda conhecer aqueles com quem poderia, ou não, fazer $\operatorname{contratos}^{44}$, e ver-se-ia cruzado com aqueles que deviam pagar a dízima à sua igreja e que, no seu quotidiano, desempenhavam variados ofícios, cada qual de seu saber. 
Toda esta multiplicidade e variedade de tarefas exigia cuidados, por vezes também saberes, nem sempre daqueles que as escolas pudessem dar, mas daqueles que a vida e a experiência ajudavam cada um a adquirir e aperfeiçoar. No seu conjunto, elas colocam-nos perante o problema da ilustração do clero. Quando e onde se fazia? Entramos, assim, na problemática, vasta, da formação intelectual do clero, ou, dito de outro modo, da aquisição dos saberes do clero na Idade Média.

Segundo estudos consagrados, há muito, o clero medieval nem tinha formação assinalável, nem eram numerosas as escolas em que a poderia obter (CAEIRO, 1968; PEREIRA, 1994). É sabido que este aspecto ocupou verdadeiramente a Igreja desde o séc. XI, conhecendo-se a acuidade que apresentou nos séc. XII e XIII, nas constituições dos concílios de Latrão III e IV, respectivamente ${ }^{45}$.

Porém, cremos que o problema é bem mais vasto, sobretudo no caso do clero peninsular, particularmente o português, aquele que agora nos ocupa. Também neste campo, a ocupação muçulmana da Península tinha desconstruído uma tradição de formação escolar dos clérigos que os concílios da época visigótica teimavam em manter e fazer crescer. Assim, só à medida que as dioceses foram sendo restauradas é que se foram podendo criar e desenvolver as condições para a recuperação dessa tradição, cada vez mais tornada necessidade. Lentamente, surgiram as escolas catedrais e até paroquiais; no caso das primeiras, seriam, porventura, recuperação de antiga tradição da época visigótica, em algumas situações. Mas neste processo há também que ter em conta as vicissitudes próprias do percurso de vida das dioceses portuguesas, na sua restauração, afirmação, relações com o poder político, pelo que não houve ambiente nem condições para um incremento e muito menos, florescimento dessas escolas entre nós, de um modo geral. É isso que justifica que Braga e Coimbra tenham sido verdadeiras excepções a esse ambiente de deserto intelectual.

As escolas catedrais funcionavam em regime de internato e nelas se seguiam os programas de estudos da Baixa Antiguidade, à volta do septivium, adaptados às condições e necessidades dos jovens dos séculos XII e XIII. No trivium os jovens versavam-se nas matérias linguísticas, da palavra, com estudos de Gramática, Retórica e Dialéctica; no quadrivium, estudavam Aritmética, Geometria, Astronomia e Música. Era na Gramática que, unida à leitura, se fazia a aprendizagem dos textos clássicos e patrísticos, ocasião para se introduzirem matérias de índole teológica para a 
compreensão da Sagrada Escritura e aquisição de conhecimentos (por rudimentares que fossem) para a função clerical e o ministério sacerdotal (MACEDO, 1997).

Porém, à medida que o tempo corria, também em Portugal se foram sentindo os influxos do que, de melhor, se fazia pela Europa, com estudantes a sair do reino para fazerem a sua formação além-Pirinéus ${ }^{46}$. E chegaria o momento de, também em Portugal, se fundar uma daquelas escolas cuja criação representa uma das maiores heranças de toda a Idade Média, as universidades. A partir daí, o problema da formação clerical deverá ser enquadrado de outra forma, pelo menos nas suas linhas gerais ${ }^{47}$. De qualquer modo, foi problema que se manteve, pois que ainda é patente a preocupação da formação do clero nos sínodos de finais do séc. XV.

Em plena Idade Média, as escolas catedrais davam a sua contribuição nas cidades, junto das Sés diocesanas, orientando-se, portanto, para a formação de um clero urbano, catedralício e de colegiadas, quando muito. Mas como ficava o caso do clero rural, pobre, desconhecido, ignorante? E que lhe restava, à medida que a política beneficial da Santa Sé permitia a acumulação de benefícios a uns, com a passagem da exigência dos serviços a outros?! E não podemos esquecer que a Cristandade era, maioritariamente, rural. A leitura das constituições sinodais medievais, permite concluir que havia muito de empírico, muito de prático na formação do clero do tempo. Seriam os próprios sacerdotes que iniciariam alguns jovens, a quem achariam algumas qualidades ou capacidades para o serviço eclesial ${ }^{48}$. Depois, a prática, o gosto e a maior ou menor consciencialização da importância da sua função acabariam por fazer o resto, isto é, por dar a melhoria das suas capacidades, que os poderiam levar aos estudos e à ordem sacerdotal. Isto é, a formação intelectual do clero na Idade Média, sobretudo do clero rural, teve muito de empírico, de “exercital” (MACEDO, 1997, p. 48).

\subsection{O(s) saber(es) dos outros}

Este último aspecto interessa-nos sobretudo pelas informações que nos fornece acerca da interacção da Igreja e da sociedade, nas muitas e expressivas actividades que executavam os homens e mulheres obrigadas ao pagamento da dízima pessoal e que nos revelam muitos desses saberes do mundo medieval com os quais os clérigos se cruzavam. As constituições sinodais reflectem tudo isso, podendo mesmo 
considerar-se também como espelho das respectivas sociedades diocesanas. É no sínodo do Porto, do ano de 1496, no de Braga, de 1505, e no da Guarda, de 1500, que se encontram as indicações mais completas sobre a matéria, não obstante poderem colherse num ou noutro dos restantes ${ }^{49}$.

A longa lista de bens sobre os quais incidia esse pagamento, bem como as actividades desenvolvidas por aqueles que ficavam sob a alçada dos dízimos pessoais, coloca-nos perante um sem número de saberes ligados, afinal, à manutenção da sociedade. Era a pecuária e o segredo da criação dos mais diversos animais, de grande ou pequeno porte, até à cresta dos enxames, produção do queijo ou da lã. Era também a produção dos mais variados legumes, e a produção, o corte e a serração das madeiras mais preciosas da floresta local, o castanho e o carvalho.

Somos também colocados perante um conjunto muito alargado de saberes que conformavam actividades desempenhadas maioritariamente por homens e que respondiam a necessidades da sociedade, algumas delas do mais comum quotidiano. Eram os ofícios dos panos, com a presença de tecelões ${ }^{50}$ e tecedeiras, tosadores e alfaiates; dos couros, com os curtidores, sapateiros, seleiros, correeiros; da cera, com a referência aos cerieiros; da construção, com os pedreiros, carpinteiros, pintores; do ferro, com os ferreiros e ferradores; do barro, com os oleiros, polivalentes, tanto a produzir louça, como ladrilho e telha. A sociedade não prescindia dos ofícios de carniceiro e magarefe ${ }^{51}$, pescador $^{52}$, moleiro (de moinho e de pisão), lagareiros (de azeite), forneiros e forneiras, tanoeiro, ourives, barbeiro. Do mesmo modo, o funcionamento da sociedade requeria artistas que, a partir de madeiras moles, produzissem objectos vários, de finalidades múltiplas ao quotidiano, como escudelas, talhadores, gamelas, ripas, trinchões, mesas, escadas, cestos, carretas, padiolas, bancos, carros, grades, arados, tudo isto destinado à venda.

Ao lado do mundo da produção, não podia faltar quem se dedicasse aos segredos da sua distribuição, que é como quem diz, à arte do negócio. Ataqueiros e marceiros, regateiras, vendeiras e vendeiros, almocreves e recoveiros, vinhateiros, trapeiros, que percorriam as feiras do reino e se aventuravam por Castela, ou mercadores de longo curso, que comerciavam na Flandres, Inglaterra ou no Levante ${ }^{53}$, 
todos tinham lugar na sociedade e caíam sob a alçada do dízimo do clero ou das suas determinações quanto àquilo que podemos chamar o período e horário de trabalho ${ }^{54}$.

Nas determinações sinodais perpassam ainda as profissões ligadas ao mundo dos saberes intelectuais, desempenhados por homens que soubessem de leis e servissem os trâmites da justiça, ou que dominassem a arte e o ofício da escrita (no seu bom e mau uso $^{55}$ ), como os advogados, tabeliães, escrivães, notários, porteiros, inquiridores, e ainda os que detivessem conhecimentos que garantissem os cuidados em caso de doença ${ }^{56}$ ou em hora de recorte problemático, como o parto ${ }^{57}$.

Por oposição a este mundo de saberes específicos e profissões próprias, contavam-se inúmeros indivíduos, homens e mulheres, de saberes indiferenciados, que ganhavam a vida de diversas formas, por regra ao serviço dos outros, como os cavões, braceiros, ganhadeiros, mancebos e mancebas de soldada, os que iam "à Estremadura gançar dinheiro a cavar ou a outros serviços”, ou aqueles cujas actividades se mesclavam de saberes vários, não conformes à tipificação convencional, como os que iam "à feira da Guarda e de Trancoso e compravam bezerros para criar e depois vender", ou aqueles que, escudeiros e outros homens e mulheres que não tinham "officios nem mesteres e tresfeguam ho mundo em comprar e vender bestas ou bois ou vacas ou outras cousas" (Synodicon, p. 174-175, 393). Não ficavam de fora as $\operatorname{amas}^{58}$ e as mulheres que andavam a ganhar dinheiro.

A todos estes saberes que alimentavam a vida, nos seus múltiplos aspectos e necessidades materiais, há que juntar aqueles que pretendiam ajudar a torná-la mais leve, permitindo a folga e a festa e que o homem sempre cultivou, ou aqueles outros que, remontando a tempos imemoriais, reminiscências de práticas pagãs, representavam uma tentativa de o homem se libertar de perigos e ameaças, dominando as forças da natureza e o futuro, desconhecido.

De um modo geral, os primeiros estão ligados às artes - música, canto, teatro - e são visados nos sínodos porque eram propícios ao excesso, logo, ao pecado, quanto mais não fosse pelo desrespeito da casa de Deus, pois, muitas vezes, as ocasiões de festa ligavam-se a ocorrências religiosas e esses momentos de diversão eram realizados nas igrejas ou rapidamente a elas se estendiam. Referimo-nos a práticas que 
contavam com a participação de momos e histriões, tocadores - dos mais variados instrumentos, como alaúdes, guitarras, pandeiros, órgãos -, cantadores e bailadores, jograis, e podiam constar ainda de representações teatrais, com homens a vestirem-se de mulher e mulheres a vestirem-se de homem, ou fazendo-se de imperadores, reis e rainhas.

Já os segundos são bem mais dispersos e difusos, sobretudo porque se tratava de saberes ocultos, apenas ao alcance de alguns, porque considerados de alguma magia ou ilicitude. De um modo geral, representavam perigo para qualquer homem, cristão, por maioria de razão. Aliás, a algumas dessas práticas, nem os próprios sacerdotes lhes ficavam imunes. Tratava-se de práticas divinatórias, esconjuros, feitiçaria, onde, por vezes, nem o sacrilégio estava ausente, e algumas se ligavam ainda às tradições pagãs ${ }^{59}$. Havia ainda outras, que caíam sob a alçada da Igreja, infringindo os seus preceitos, pois representavam atentado contra a natureza, a vida humana e a liberdade, como fossem o uso de práticas anti-concepcionais, o recurso a expedientes atentatórios da vida humana e a alcovitice ${ }^{60}$.

Foi razoavelmente longa a excursão que fizemos pelas competências exigidas ou referidas, implícita ou explicitamente, na legislação sinodal portuguesa da Idade Média. Proveniente de clérigos, destinava-se aos clérigos, na cadeia hierárquica que conformava esse grupo na sociedade, tentando fornecer-lhe pistas de aprendizagem e actuação com vista a um desempenho digno da sua função social. Logo, incidiria, e em primeiro lugar, sobre o conhecimento da doutrina e dos rituais litúrgicos. $\mathrm{Na}$ ausência de uma exigência absoluta de formação ou de possibilidade de uma formação aturada, com suas escolas e programas, muitos deles limitavam-se a uma aprendizagem empírica, que, no futuro, poderia ser, ou não, completada e aprofundada pelos estudos formais. Fosse como fosse, não se pode negar que foi este clero rural, submetido ao poder episcopal e tantas vezes ignorante dos saberes formais, que cristianizou o Ocidente ou, particularizando, o Portugal que se conquistava à força da espada (AUBRUN, 1995, p. 27).

$\mathrm{Na}$ interacção deste grupo com a sociedade, os leigos não podiam ficar de fora da nossa análise, pois que também eles detinham saberes específicos indispensáveis ao bom governo e ao fim último da respublica christiana. 
Se é verdade que, para os clérigos, sobressaem, de um modo geral, os saberes informais, das práticas do quotidiano, que se aprendiam na vida do dia-a-dia, numa aprendizagem que atravessava o tempo e unia gerações, isso é ainda mais verdadeiro para os leigos, na grande maioria das actividades que lhes cometem as constituições sinodais.

Dentre esses saberes, claramente se evidenciavam aqueles que eram detidos e exercidos por homens e cristãos. Não que as mulheres não fizessem parte do povo de Deus, logo das preocupações dos responsáveis diocesanos, ou que não colaborassem na manutenção da sociedade. Isso mesmo decorre de referências a certas actividades, como indicámos. Porém, como em tantos outros campos da vida na Idade Média, a mulher fica escondida, na rotina dos dias, na repetição das tarefas, no exercício dos seus saberes e das suas artes maioritariamente de portas a dentro. Valha a verdade que a legislação sinodal lhes reconhece lugar primordial no que à vida diz respeito, enquanto as indica como parteiras e amas. Mas, ferida do pecado original da sua génese, a legislação sinodal não deixa de ver, nelas, as filhas de Eva, sedutoras e pecadoras, de muito mais ribalta enquanto protagonistas necessárias do fenómeno da barregania clerical.

Por outro lado, na insistência dos cristãos relativamente ao afastamento possível de saberes de outros membros da sociedade, por razões religiosas, os responsáveis da Igreja portuguesa pugnavam por uma praxis marcada pela ortodoxia estrita e mostravam-se bem a caminho da atitude segregacionista que o futuro mais ou menos próximo havia de confirmar.

\section{THE KNOWLEDGE IN THE PORTUGUESE SYNODAL LAW OF THE MIDDLE AGES}

ABSTRACT: During the Middle Ages and at the accomplishment of the apostolic obligations, the Portuguese bishops were reunited to theirs clergy and, in its set, trying to trace the lines that seemed more adequate to the salvation of the herd that was trusted to them. In the law produced and which has reached us, it's possible to asses something of which the Portuguese Clergy's responsible understood as a necessary knowledge to the clergy corpse, as well as it may be looked at a whole set of knowledge that were necessary to unfold the religious and clerical's life in medieval Portugal. This way, in the interaction of the clergy with the Christian people, we may still cross ourselves with diversified knowledge, sometimes in practices that conflict themselves with the idea of orthodoxy and hierarchy of the medieval Portuguese clergy. 
Keywords: Clergy, Middle Ages, To Know, Knowledge.

\section{EL SABER Y LOS SABERES EN LA LEGISLACIÓN SINODAL PORTUGUESA DE LA EDAD MEDIA}

RESUMEN: A lo largo de la Edad Media y en el cumplimiento de su misión apostólica, los obispos portugueses se reunían a su clero y, en conjunto, intentaban trazar las líneas que les parecían más apropiadas para la salvación del rebaño que les fue asignado. En la legislación producida y que ha llegado hasta nuestros días se puede evaluar algo de lo que los responsables por el clero portugués entendían como el saber necesario al cuerpo clerical, así como se puede mirar todo un conjunto de saberes que eran precisos para la realización de la vida religiosa y del clero en el Portugal medieval. Así como en la interacción del clero con el pueblo cristiano, todavía se puede cruzar con saberes varios, a veces en prácticas que entraban en conflicto con la idea de la ortodoxia de la jerarquía del clero portugués medieval.

PALABRAS CLAVE: Clero, Edad Media, saber y saberes.

\section{NOTAS}

${ }^{1}$ Trata-se, evidentemente, de sínodos diocesanos, pois que podem ser considerados outros. Aliás, serão os deste tipo e reunidos durante a Idade Média, o alvo da nossa atenção. A sua produção normativa foi publicada por COSTA, Avelino de Jesus da, e PEREIRA, Isaías da Rosa Pereira (ainda, CANTELAR RODRIGUEZ, Francisco, GARCIA y GARCIA, António, e GUTIERREZ RODRIGUEZ, Antonio) na obra Synodicon Hispanum. Sempre que nos referirmos a esta obra, fá-lo-emos apenas por Synodicon, citando os sínodos por diocese e data, seguidas das constituições em causa.

2 Uns referem a assembleia presidida por S. Paulo, em Jerusalém, como o momento primordial destes mecanismos, enquanto outros referem a reunião do papa Siríaco, com o clero de Roma e diversos bispos, em Roma, no ano de 389.

${ }^{3}$ Veja-se, por exemplo, Braga: 1403, c. 1 (Synodicon, p. 319).

${ }^{4}$ Braga: 1307, c. 17 (Synodicon, p. 311).

${ }^{5}$ Braga: 1505, c. 1; Lisboa: 1240, c. 1; Porto: 1496, c. 1 (Synodicon, p. 142, 286, 356). Advertimos o leitor para o facto de as constituições do sínodo do Porto: 1496 serem quase iguais, em grande maioria, às do de Braga: 1505. O legislador foi o mesmo, D. Diogo de Sousa, bispo do Porto entre 1496-1503, e arcebispo de Braga a partir de 1505; cfr. Synodicon, p. 138-139.

${ }^{6}$ Braga: 1281, c. 30; Braga: 1326, c. 1; Braga: 1364, c. 11; Braga: 1477, c. 2; Braga: 1505, c. 7; Valença do Minho: 1444, c. 6 (Synodicon, p. 30, 39, 52, 77-78; 144-145; 428). Braga: 1477, c. 2, pode considerarse um verdadeiro figurino de um clérigo rico e ostentador, que, mesmo assim, ainda poderia ajustar novo requinte a Braga: 1505 , c. 7.

${ }^{7}$ No sínodo de Lisboa de 1403, expressamente se diz que a reunião demoraria 3 dias. Os convocados deveriam chegar a 5 de Maio, para o sínodo se iniciar a 6, dia de São João ante Portam latinam (São João Evangelista). Relativamente ao tempo da reunião, era uma inovação, uma vez que, desde 1307, episcopado de D. João Martins de Soalhães, a diocese de Lisboa tinha data para o sínodo, 11 de Junho, dia de São Barnabé. Ver Lisboa: 1307, c. 17 e Lisboa: 1403, c. 1 (Synodicon, p. 311 e 319 , respectivamente).

${ }^{8}$ É interessante questionar a presença dos clérigos nos sínodos pela outra face, sua oposta, isto é, a ausência das suas paróquias, no caso do clero paroquial. Alguns sínodos também se ocuparam de tal questão. Por exemplo, Lisboa: 1307, c. 17 determina que os clérigos vindos ao sínodo deviam providenciar um outro, ou capelão, para dizer as horas e ministrar os sacramentos enquanto durasse o sínodo (Synodicon, p. 311). 
${ }^{9}$ Esta ideia de adaptação, complemento e inovação está bem clara nos prólogos dos sínodos de Braga: 1505; Guarda: 1500; Lisboa: 1430 e Valença do Minho: 1444 (Synodicon, p. 140, 224, 319, 424-425, respectivamente).

10 Adoptamos as indicações cronológicas da obra que nos serve de fonte, sendo que consideramos também as informações transmitidas na introdução a cada diocese.

${ }^{11}$ No último quartel reuniram-se 11 sínodos dos 32 do século.

${ }^{12}$ E dessas 10, 7 realizaram-se entre 1364 e 1398, notando-se anos seguidos e interpolados

13 Tratamos esta matéria no nosso trabalho "A igreja portuguesa ao tempo de Inês de Castro: homens e problemas", a publicar nas Actas do Congresso Internacional "Pedro e Inês": o futuro do passado (no prelo).

14 É óbvio que as quadras vazias na coluna "Legislação" dos diversos sub-quadros do Quadro II equivalem ao desconhecimento do número de constituições produzidas nas reuniões assinaladas.

${ }^{15} \mathrm{Na}$ verdade, só em número muito reduzido podemos afirmar que foram as que eles produziram, pois, em grande número de casos, o que hoje, conhecemos, é a transcrição de alguma ou algumas constituições que, por qualquer motivo de gestão diocesana, um bispo, posterior, entendeu por bem publicar de novo. Curioso, a este título, é o que se passa em Évora, com o bispo D. Luís Pires. Tendo reunido dois sínodos, em anos consecutivos, apenas se conhece uma constituição de cada um deles, sendo que a do primeiro se conhece por cópia inserta em notícia sobre o segundo, apresentando a indicação de que ela era uma das 39 constituições nele produzidas. Do que nos chegou, é interessante notar que, de um modo geral, as constituições são mais longas à medida que o tempo corria, o que tanto pode constituir uma questão de sorte, como (e é o que mais nos parece) ser sinónimo de responsáveis mais esclarecidos e mais dedicados, logo, mais cuidadosos nos parece) ser sinónimo de responsáveis mais esclarecidos e mais dedicados, logo, mais cuidadosos no seu ministério.

${ }^{16}$ Synodicon, p. 26 e 134-135 (Braga: 1281, c. 49 e Braga: 1477, c. 61, respectivamente). O prazo indicado por D. Luís Pires não é explícito, mas decorre de as constituições terem sido aprovadas a 11 de Dezembro de 1477 e as cópias deverem estar devidamente autenticadas nas paróquias e mosteiros da diocese até à Páscoa seguinte. Porém, três anos volvidos, ainda o mesmo arcebispo se via obrigado a fulminar pena de excomunhão contra aqueles que "nunca dello curarom nem oje curam e se leixam encorrer nas pennas na dicta constituiçom contheudas", em atitude que o arcebispo entendia de "mal, despreço, desobediencia, negligencia e contumacia" (ibidem, p. 136-137). O mesmo prazo de um ano era concedido em Lisboa, no início do séc. XIV, por D. João Martins de Soalhães (1307, c. 30; Synodicon, p. 314). Na variedade que caracterizou a Idade Média, também neste ponto ela se verificava. Aos prazos indicados, poderemos acrescentar o de 6 meses em Braga: 1326, c. 9 e Lisboa: 1403, c. 28 ; 5 e 3 meses em Valença do Minho: 1444, c. 31 e 1486, c. 8; e 2 meses em Évora: 1344, c. 8 (Synodicon, p. 44, 337 , 442, 455 e 208-209).

${ }^{17}$ Braga: 1477, c. 62 (Synodicon, p. 135).

${ }^{18}$ Braga: 1505, c. 58; Porto: 1496, c. 40 (Synodicon, p. 135 e 384).

${ }^{19}$ O mais expressivo e completo é o do Porto: 1496, c. 60 (Synodicon, p. 403-405). É também interessante Braga: 1477, c. 58 (Synodicon, p. 131).

${ }^{20}$ Ibidem, c. 44 e 47 (Synodicon, p. 117, 119-120). Na segunda constituição referida diz-se textualmente: "nas egrejas que som casas, paaços de Deus, as quaaes ham de seer linpas e despejadas, em que os fiiés christãaos possam star e fazer suas oraçõoes e prezes ao seu Deus e Senhor sem outra torvaçam per que sejam desviados ou torvados de seus boons prepositos e devaçõoes".

${ }^{21}$ Guarda: 1500, c. 3; Lisboa: 1240, c. 2 (Synodicon, p. 226-227, 287).

${ }^{22}$ Guarda: 1500, c. 55; Porto: 1496, c. 21 (Synodicon, p. 254, 369-370).

${ }^{23}$ Eles representavam os objectos que mais proximamente contactavam com o Corpo de Cristo e serviam ao mistério da eucaristia.

${ }^{24}$ Braga: 1477, c. 35 (Synodicon, p. 109). Guarda: 1500, c. 19, não refere expressamente a utilização da linguagem vulgar, mas entende-se que dela se trata (Synodicon, p. 237).

25 Braga: 1505, c. 28; Porto: 1496, c. 30 (Synodicon, p. 162 e 377). Do Natal à Páscoa era tempo de aprendizagem dos preceitos e mandamentos e pecados mortais; da Páscoa a Santa Maria de Agosto (15), o Pater noster, Ave Maria, Credo in Deum, obras de misericórdia; de Santa Maria de Agosto até ao Natal, os sacramentos da Igreja, os cinco sentidos e as virtudes teologais e cardeais.

${ }^{26}$ Braga: 1477, c. 35 (Synodicon, p. 109). Rezar: Pater noster, Ave Maria, Credo in Deum; crer: artigos da fé; cumprir: preceitos da lei e obras de misericórdia; guardar-se: sete pecados mortais.

${ }^{27}$ Braga: 1505, c. 34; Porto: 1496, c. 36 (Synodicon, p. 166 e 381). Estes registos seriam feitos a partir de um sumário mandado fazer pelos respectivos bispos e deveriam estar prontos dentro de um prazo de 4 meses, a partir da publicação das constituições que contém a determinação.

${ }^{28}$ Braga: 1281, c. 30; Braga:1505, c. 7; Lisboa: 1307, c. 23; Lisboa: 1403, c. 5; Porto: 1496, c. 8; Valença do Minho: 1444, c. 6 (Synodicon, p. 109, 144-146, 312, 323-324, 359-361, 428). 
${ }^{29}$ Braga: 1281, c. 30 e 36; Braga: 1505, c. 7; Porto: 1496, c. 8 (Synodicon, p. 20-22, 144-146, 359-361).

${ }^{30}$ Braga: 1281, c. 39; Braga: 1477, c. 50; Braga: 1505, c. 7; Porto: 1496, c. 8; Valença do Minho: 1444 , c. 8 (Synodicon, p. 21, 122-123, 144-146, 359-361, 429).

${ }^{31}$ Braga: 1505, c. 12; Guarda: 1500, c. 65; Lisboa: 1248, c. 12; Porto: 1496, c. 14; Valença do Minho: 1444, c. 10 (Synodicon, p. 148, 258, 300, 430).

${ }^{32}$ Braga: 1281, c. 34; Guarda: 1500, c. 65 (Synodicon, p. 21, 258).

${ }^{33}$ Valença do Minho: 1444, c. 13 (Synodicon, p. 431-432).

${ }^{34}$ Nomeadamente de pão e vinho e as actividades de intermediação, sobretudo em rendas; cfr. Braga: 1281, c. 36; Porto: 1496, c. 13; Valença do Minho: 1444, c. 9 (Synodicon, p. 21, 363, 429).

${ }^{35}$ Nomeadamente de pão e vinho e as actividades de intermediação, sobretudo em rendas; cfr. Braga: 1281, c. 36; Porto: 1496, c. 13; Valença do Minho: 1444, c. 9 (Synodicon, p. 21, 363, 429).

${ }^{36}$ Guarda: 1500, c. 61 (Synodicon, p. 256). Sobre os jogos, também Lisboa: 1240, c. 16 (Synodicon, p. 293).

${ }^{37}$ Braga: 1281, c. 32 (Synodicon, p. 21).

${ }^{38}$ Braga: 1477, c. 15, 29; Braga: 1505, c. 18; Guarda: 1500, c. 21 (Synodicon, p. 90, 102, 153-154, 370).

${ }^{39}$ Braga: 1477, c. 13 (Synodicon, p. 89); Braga: 1477, c. 3; Porto: 1496, c. 4 (Synodicon, p. 81, 357-358)

${ }^{40}$ Braga: 1477, c. 13 e 59 (Synodicon, p. 89 e 132-133). Às alfaias da eucaristia juntavam-se as cruzes e os relicários.

${ }^{41}$ Braga: 1477, c. 59 (Synodicon, p. 132-133).

${ }^{42}$ Braga: 1477, c. 42; Porto: 1496, c. 42 (Synodicon, p. 113-114, 386-387); ${ }^{1}$ Braga: 1281, c. 18 e 19; Guarda: 1500, c. 79; Lisboa: 1307, c. 7; Lisboa: 1403, c. 15; Valença do Minho: 1444, c. 25 (Synodicon, p. 16, 267-268, 308, 330-331, 437).

${ }^{43}$ Braga: 1333, c. 2; Braga: 1477, c. 43; Guarda: 1500, c. 76-78; Porto: 1477, c. 19; Valença do Minho: 1444, c. 11 (Synodicon, p. 48-49, 115-117, 265-267, 367-368, 430-431).

${ }^{44}$ Judeus e mouros; Braga: 1326, c. 6; Braga: 1477, c. 43 (Synodicon, p. 43, 115-117).

${ }^{45}$ C. 18 e c. 11 , in Les conciles oecuméniques. 2. Les décrets, p. 474-475 e 514-515, respectivamente.

${ }^{46}$ Citem-se as medidas do arcebispo D. João Peculiar e de D. Sancho I, o primeiro autorizando que qualquer cónego que, devidamente autorizado, fosse frequentar os estudos, receberia a sua porção canónica enquanto neles estivesse; o segundo, concedendo bolsas de estudo a clérigos que quisessem ir estudar para Paris.

47 Justifica-se este nosso excurso, uma vez que é largo o âmbito cronológico da documentação que percorremos.

${ }^{48}$ Isto mesmo se depreende da constituição 7, do sínodo de Braga de 1477: “Que castiguem os moços que tenham silencio e asesseguo aos ofícios divinos e que nom leam pollos livros da egreja" (Synodicon, $\mathrm{p}$. 85). Esclareça-se que a última determinação não se aplicava a todos, apenas aos que, mais jovens, ainda não sabiam ler nem cantar. A esses, deveriam ser seus pais e suas mães a buscar-lhes os livros, deixando, assim, a boa guarda, os das igrejas e mosteiros.

49 Deste modo, e para não sobrecarregarmos o texto com indicação de notas de rodapé, apenas indicaremos os casos específicos da Guarda e algum outro, que, acaso, exista. Por regra (e por omissão, no texto), ficam os sínodos de Braga: 1505, c. 42 e Porto: 1496, c. 48 (Synodicon, p. 173-175 e 391-393). ${ }^{50}$ Apenas presentes em Guarda: 1500, c. 80 (Synodicon, p. 268-269).

${ }^{51}$ O magarefe está referenciado apenas em Guarda: 1500, c. 24 (Synodicon, p. 239-240).

${ }^{52}$ Quando especificado, é actividade apresentada com as suas adaptações ao meio: lampreias no Norte do território e trutas na Beira. A constituição acerca da pesca dos sáveis, no Porto, sendo importante a esta análise, foi introduzida com outro objectivo, que não a cobrança do dízimo (cfr. Synodicon, p. 394-395).

${ }^{53}$ Este comércio está ausente da Guarda, como não podia deixar de ser, atendendo à via por que se fazia, a marítima.

54 É o que podemos considerar sobre os "especieiros e enxerqueiros, regatõoes, padeiras, verceiras, taverneiras, fruyteiras e mostardeiras" que não deveriam vender ao domingo e dias santos de guarda, antes de missa (Braga: 1477, c. 55; Synodicon, p. 128; de igual significado, mas sem a especificidade do nome do ofício em Guarda: 1500, c. 24; Synodicon, p. 239-240).

${ }^{55}$ Pois também se consideram os falsários de "letras ou seeellos ou outras scritpuras" (Lisboa: 1403, c. 3; Synodicon, p. 320-322).

${ }^{56}$ Especificamente estes últimos acham-se em Braga: 1477, c. 55; Porto: 1496, c. 59 (Synodicon, p. 128, 402). Em Lisboa: 1403 , c. 23 , o saber médico está ligado aos judeus, a quem, aliás, os cristãos não deveriam recorrer (Synodicon, p. 334-336).

${ }^{57}$ Braga: 1477, c. 57; Lisboa: 1403, c. 23 (Synodicon, p. 130-131, 334-336). Enquanto no primeiro caso, as parteiras são cristãs e a constituição sinodal permite que elas acudissem a mulheres judias, no segundo caso a referência é a médicos judeus, aos quais as cristãs não deviam recorrer.

Hist. R., Goiânia, v.18, n. 1, p. 91-120, jan. / jun. 2013 
Braga: 1477, c. 57; Lisboa: 1403, c. 23 (Synodicon, p. 130-131, 334-336). Enquanto no primeiro caso, as parteiras são cristãs e a constituição sinodal permite que elas acudissem a mulheres judias, no segundo caso a referência é a médicos judeus, aos quais as cristãs não deviam recorrer.

${ }^{58}$ Mas as mulheres cristãs não poderiam criar filhos de judeus; cfr. Lisboa: 1307, c. 9 (Synodicon, p. 308309).

${ }^{59}$ Braga: 1477, c. 46; Guarda: 1500, c. 64; Lisboa: 1403, c. 3 e 23 (Synodicon, p. 119, 320-322, 257-258, 334-335). É interessante notar a justificação das penas em que incorriam os feiticeiros, benzedeiros e agoureiros, homens e mulheres: "só a Deus nosso Senhor é atribuído saber as cousas escondidas e assim as que hão de vir e não $<a>$ outra pesoa alguma, porém muitos homens e mulheres, pouco lembrados de suas consciências e quanto em esto a Deus ofendem, querem atribuir assim o atribuído a ele só Deus fazendo-se feiticeiros, adivinheiros, encantadores, sorteiros, agoureiros, benzedeiros, usando de outras semelhantes artes". Isto é, reclama-se a omnisciência divina e sublinha-se a infimidade e presunção humanas.

${ }^{60}$ Lisboa: 1403 , c. 23 , onde claramente há referência a práticas "pera a mulher nom emprenhar", ou às mulheres que "fazem algûas coussas pera matarem seus maridos" e o uso "dalcouveteira enduzendo molher veuva ou cassada ou moça virgem pera corupçom e deshonestidade” (Synodicon, p. 335).

\section{REFERENNCIAS}

AUBRUN, Michel. Le clergé rural dans le royaume franc du $\mathrm{VI}^{\mathrm{e}}$ au XII $\mathrm{X}^{\mathrm{e}}$ siècle. Le clergé rural dans l'Europe médiéval et moderne. Actes des XIIIèmes Journées Internationales d'Histoire de l'Abbaye de Flaran. 6-8 septembre 1991. Études réunis par Pierre Bonnassie. Toulouse : Presses Universitaires du Mirail, 1995, p. 15-40.

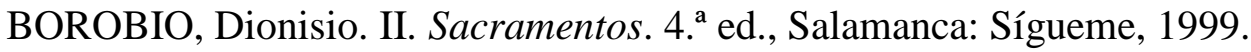

BOROBIO, Dionisio. I. Liturgia y sacramentologia fundamental. 5. ${ }^{a}$ ed., Salamanca: Sígueme, 2000.

CAEIRO, Francisco da Gama. A organização do ensino em Portugal no período anterior à fundação da Universidade. Separata de Arquivos de História da cultura portuguesa, II, n. ${ }^{\circ}$ 3, Lisboa: s.n., 1968.

COSTA, Avelino de Jesus da. Sínodos e Constituições Diocesanas”. Aç̧ão Católica, vol. XXVI, 1941.

Documentos de D. Sancho I: 1174-1211. Ed. Rui de Azevedo, Avelino de Jesus da Costa e Marcelino Rodrigues Pereira. Coimbra: Centro de História da Universidade de Coimbra, 1979.

DUQUE, João. Sínodo. Elementos para uma fundamentação teológica. In: Theologica, II. ${ }^{a}$ série, XXX, fasc. 2, 1995, p. 235-251.

GARCIA y GARCIA, Antonio. II. Portugal. Madrid: BAC, 1982.

GAUDEMET, Jean. Église et cité. Histoire du droit canonique. Paris : ed. du Cerf Montchrestien, 1994. 
Les conciles oecumeniques. De Nicée à Latran V. Sous la direction de ALBERIGO, G. II-I, Les décrets. Paris : Les Éditions du Cerf, 1994, can. 6.

Liber Fidei Sanctae Bracharensis Ecclesiae. Ed. P. 'Avelino de Jesus da Costa, III, Braga: Junta Distrital de Braga, 1990.

LÓPEZ MARTÍN, Julián. La liturgia de la Iglesia. Madrid: Biblioteca de Autores Cristianos, 2009.

MACEDO, José Adílio Barbosa. O clero e a sua formação. De Jesus Cristo ao Concílio de Trento. Braga: s.n., 1997.

MARQUES, José. "Sínodos Bracarenses e renovação pastoral” Theologica, II. série, vol. XXX, fasc. 2, 1995.

MARQUES, Maria Alegria. Concílios Provinciais. Dicionário de História Religiosa de Portugal. Direcção de Carlos Moreira Azevedo. Lisboa: Círculo de Leitores, v. I, 2000.

As minorias na legislação sinodal portuguesa medieval. Separata de Minorias Étnicas e Religiosas em Portugal. História e Actualidade. Actas do Curso de Inverno 2002. Coordenação de Guilhermina Mota. Coimbra: Instituto de História Económica e Social da Faculdade de Letras da Universidade de Coimbra, 2003, p. 33-47

O papado e Portugal no tempo de D. Afonso III (1245-1279). Coimbra: Faculdade de Letras da Universidade de Coimbra, 1990.

NAZ, R. Synode. Dictionnaire de Droit canonique. Paris : Librairie Letouzey et Anê, v. VII, 1965, cols. 1134-1140.

PAIVA, José Pedro. Sínodos Diocesanos. I. Época Medieval e Moderna. Dicionário de História Religiosa de Portugal. Lisboa: Círculo de Leitores, IV, 2000, p. 240-247.

PEREIRA, Isaías da Rosa. A formação do clero antes do concílio de Trento. Separata de Actas do Congresso de História no IV centenário do Seminário de Évora. I, Évora: s/ ed., 1994.

A vida do clero e o ensino da vida cristã através dos sínodos medievais portugueses (séculos XIII-XV). Separata de Lusitania Sacra, Lisboa, t. 10, 1978.

RÍOS RODRIGUEZ, Maria Luz, e DIEZ HERRERA, Cármen. La vie du clergé rural dans le Nord de l'Espagne médiévale d'après les actes synodaux. BONNASSIE, P. (ed.) Le clergé rural dans l'Europe médiévale et moderne. Actes des XIIIèmes Journées internationales d'histoire de l'Abbaye de Flaran, 6-8 septembre 1991. Flaran :1995. p. 167- 186.

“Sínodos e Constituições Diocesanas”, in Acção Católica, vol. XXVI, 1941.

"Sínodos Bracarenses e renovação pastoral” Theologica, II. série, vol. XXX, fasc. 2, 
1995.

SOARES, Franquelim Neiva. História breve dos sínodos e concílios da arquidiocese de Braga. Theologica. II. ${ }^{a}$ série, Braga, v. XXXII, fasc. 1, (1997), p. 119-138. 